Article

\title{
Spatial Distribution of Fecal Indicator Bacteria in Groundwater beneath Two Large On-Site Wastewater Treatment Systems
}

\author{
Charles Humphrey $^{1, *}$, Michael O'Driscoll ${ }^{2}$ and Jonathan Harris ${ }^{1}$
}

1 Environmental Health Sciences Program, East Carolina University, 3400 suite Carol Belk Building, Greenville, NC 27858, USA; E-Mail: Harrisjon@ecu.edu

2 Department of Geological Sciences, East Carolina University, 204 Graham, Greenville, NC 27858, USA; E-Mail: Odriscollm@ecu.edu

* Author to whom correspondence should be addressed; E-Mail: Humphreyc@ecu.edu; Tel.: +1-252-737-1479; Fax: +1-252-328-1285.

Received: 20 January 2014; in revised form: 11 February 2014 / Accepted: 12 March 2014 / Published: 24 March 2014

\begin{abstract}
On-site wastewater treatment systems (OWS) are a common means of wastewater treatment in coastal North Carolina, where the soils are sandy and groundwater is relatively close to the surface $(<5 \mathrm{~m})$. Wastewater contains elevated concentrations of pathogenic microorganisms that can contaminate groundwater and surface water if OWS are not operating efficiently and distributing wastewater equally to all drainfield trenches. The objectives of this study were to compare the distribution of fecal indicator bacteria (FIB) in groundwater beneath a large low-pressure pipe (LPP) OWS and a large pump to distribution box system, and to determine the effectiveness of the systems in reducing FIB including total coliform, E. coli, and enterococci. Monitoring wells were installed at the fronts and ends of the drainfields for sample collection. Groundwater beneath the LPP had a more homogeneous spatial distribution of E. coli and enterococci concentrations and the specific conductivity of groundwater was also more uniform relative to groundwater beneath the distribution box system. Both systems were effective $(>99 \%)$ at reducing FIB concentrations before discharge to groundwater. Results indicate that the LPP did enhance the distribution of FIB in groundwater beneath the drainfield area relative to the pump to distribution box system. Although the LPP system had a vadose zone over $2 \mathrm{~m}$ thinner than the pump to distribution box system, FIB treatment was similar. Enterococci was the most resilient FIB of the three tested.
\end{abstract}

Keywords: on-site wastewater; low pressure pipe; bacteria; water quality; coastal 


\section{Introduction}

On-site wastewater treatment systems (OWS) are a common method of wastewater treatment in many countries including the United States, Australia, Canada, New Zealand, and Ireland [1-5]. OWS treat wastewater that contains high concentrations of pathogenic microorganisms such as bacteria, viruses, and protozoa [1,6]. Most OWS include a septic tank, effluent distribution device, drainfield trenches, and soil beneath the trenches. The septic tank provides primary treatment via sedimentation and anaerobic digestion of organic matter. The effluent distribution device distributes wastewater to the drainfield trenches, where effluent is stored until infiltrating the soil. The soil beneath the drainfield trenches provides most of the physical, chemical and biological treatment of wastewater. If OWS do not reduce the concentration of pathogens in wastewater effluent, then groundwater and surface water quality may be degraded and public health may be compromised. For example, studies have shown that concentrations of fecal indicator bacteria (FIB) including E. coli, enterococci, total coliform, and/or fecal coliform can be elevated in groundwater adjacent to OWS if there is not sufficient vertical separation between the OWS trenches and water table [7-10]. Other research has shown that surface water FIB concentrations were elevated in areas adjacent to high densities of OWS [11] and when groundwater levels beneath OWS were elevated surface water FIB concentrations were also elevated [12]. High densities of OWS have been associated with endemic diarrheal illness, with higher OWS densities correlating to higher incidences of bacterial and viral diarrhea in a study in central Wisconsin [13].

Other factors associated with OWS wastewater treatment performance include soil type, loading rates, and system type. OWS installed in soils with higher percentages of fine-textured materials such as silt and clay, typically are more efficient at reducing microbial concentrations than OWS installed in sandy soils, due to the increased reactive surface area and residence time [7,14,15]. Research has also suggested that higher wastewater loading rates may lead to decreased treatment $[8,16-18]$ and that OWS that utilize low pressure pipe (LPP) distribution can more efficiently treat wastewater constituents such as bacteria relative to gravity flow effluent distribution systems $[16,19,20]$. LPP systems include a septic tank and pump tank, a pump that delivers effluent to the drainfield trenches via a pressure manifold connected to small diameter $(2.54$ to $5.08 \mathrm{~cm}$ ) PVC conveyance pipes (laterals) that extend the length of each trench (Figure 1). The laterals for each trench are typically the same diameter, and have small holes $(0.31$ to $0.39 \mathrm{~cm}$ ) drilled along the lateral about every $1.5 \mathrm{~m}$ (in sandy soils) to deliver wastewater to the trench. The ends of the laterals include a "turn-up" that is capped, so that when the pump is activated, the manifold and then all laterals should pressurize and thus deliver equal distribution of effluent across the drainfield. This is in contrast to OWS that use distribution boxes. Effluent distribution with distribution boxes is facilitated by gravitational forces, not pressure, even if the OWS uses a pump. The distribution box is installed at a higher elevation relative to the trenches. The distribution boxes are connected to the drainfield trenches with conveyance pipes that have larger diameter weep holes $(1.3$ to $1.9 \mathrm{~cm})$ that are more closely spaced $(10 \mathrm{~cm}$ apart $)$ together than LPP systems [21] (Figure 1). The conveyance pipes are not capped at the end, and thus often deliver more wastewater to the front of the trenches than an LPP system. Because some of the earlier studies suggested that LPP systems could perform better than conventional OWS [16,19,20], there are less stringent siting requirements for LPP systems relative to conventional systems with distribution boxes in North Carolina. For example, in sandy areas, LPP systems can be installed in soils with $15 \mathrm{~cm}$ 
less soil depth and separation to groundwater than conventional OWS [21], and LPP systems typically require about $25 \%-30 \%$ less overall drainfield area than conventional trench systems with distribution boxes [21]. If LPP systems are more effective at distributing wastewater across the entire drainfield area than gravity flow distribution systems, then groundwater characteristics (as influenced by infiltrating wastewater) beneath the LPP systems may also be more homogeneous. However, there is a lack of field research that compares FIB groundwater quality uniformity beneath OWS that use LPP and gravity flow distribution. If the LPP systems are not more effective at distributing effluent across the entire drainfield area than OWS that use distribution boxes, then the overall treatment of wastewater constituents such as pathogenic microorganisms may not be as effective as prior work has suggested.

Figure 1. Low pressure pipe (LPP) system (top) and pump to distribution box system (bottom) showing the differences in pipe diameter, weep hole size and spacing, and end of the pipes (capped for LPP, open for distribution box).

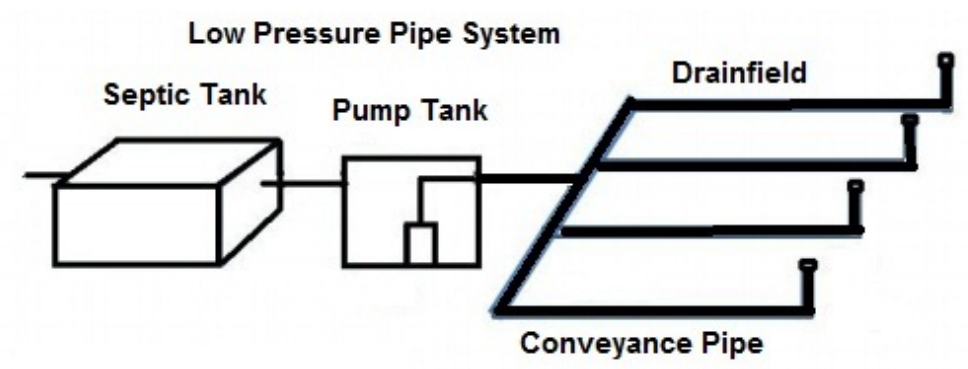

Enlarged Conveyance Pipe for LPP System
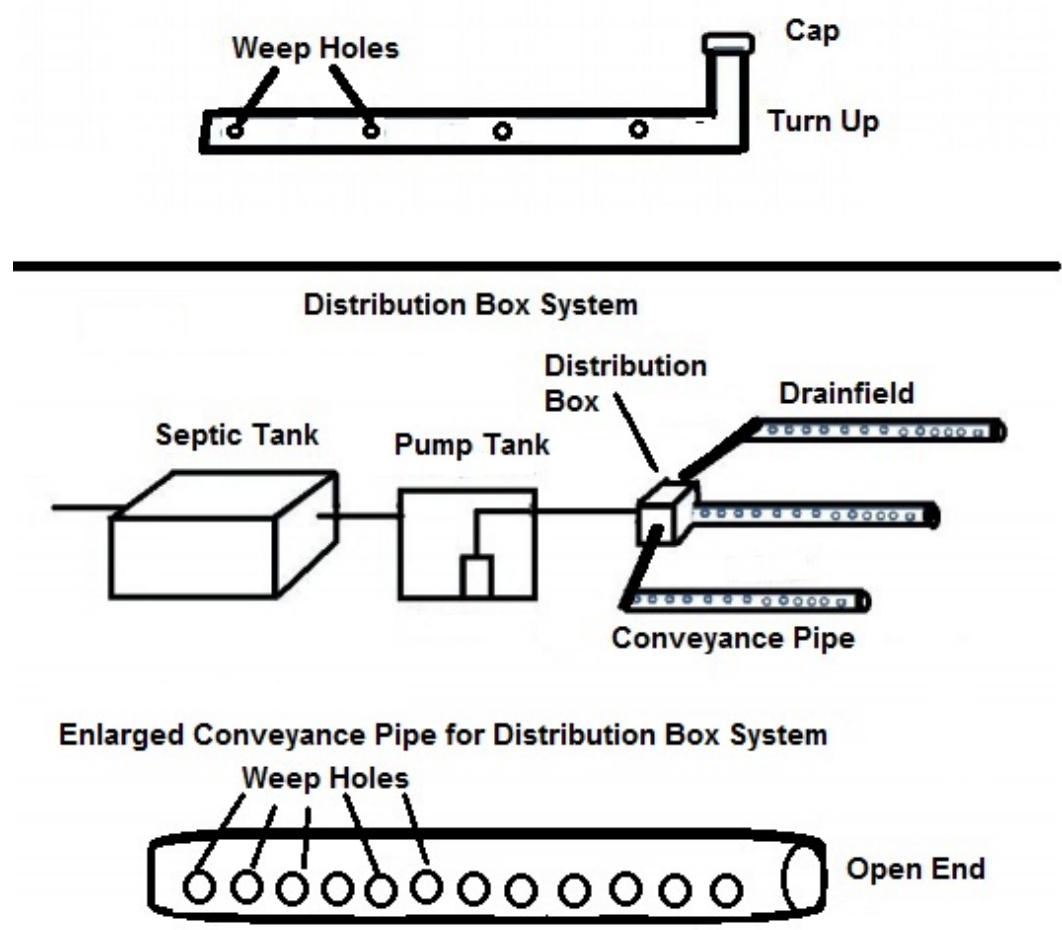
The objectives of this research were to: (1) compare the spatial variability of groundwater FIB concentrations beneath OWS that use LPP and distribution boxes for effluent distribution; and (2) evaluate the efficiency of the LPP and pump to distribution box OWS in reducing FIB concentrations.

\section{Materials and Methods}

\subsection{Site Selection}

Sites were selected at two schools in Craven County North Carolina, USA including James W. Smith Elementary (JWS) and West Craven High School (WCH). The sites were chosen because they were located in coastal North Carolina where issues regarding FIB contamination of surface waters have been documented $[8,11]$. Both schools have OWS that include large capacity septic tanks, pump tanks with effluent pumps and dual alternatingly dosed disposal fields (Table 1). The OWS at JWS and $\mathrm{WCH}$ were routinely maintained by a certified operator with oversight from the Craven County Environmental Health Department. Both systems were in operation during the study and each had 32 drainfield trenches. The OWS at WCH was a replacement system that was installed in 1997. The OWS at JWS was the original system that has been in use since 1987. The OWS at JWS uses a pump to distribution box system and WCH uses a low pressure pipe (LPP) system. Other system characteristics are listed in Table 1.

The soil survey for Craven County listed the soil series as Autryville loamy sand (Loamy siliceous, thermic, Arenic Paleudult) at JWS, and Tarboro sand (Mixed, thermic, typic Udipsamments) at WCH [22]. The soil series at the sites were confirmed by a NC Licensed Soil Scientist working on the project. Soil cores were also collected to depths of $5 \mathrm{~m}$ at each site within the drainfield area for descriptive analysis. Grain-size analysis was completed on the soil samples using the GRADISTAT 4.0 method [23]. The mean $\%$ sand from soil samples collected from the cores was $>90 \%$ for both sites.

Table 1. Site and wastewater system characteristics.

\begin{tabular}{cccccccccc}
\hline \multirow{2}{*}{ Site } & $\begin{array}{c}\text { Install } \\
\text { Date }\end{array}$ & $\begin{array}{c}\text { Septic Tank } \\
\text { Capacity (L) }\end{array}$ & $\begin{array}{c}\text { Max Design } \\
\text { Flow (L/d) }\end{array}$ & $\begin{array}{c}\text { Grease } \\
\text { Trap (L) }\end{array}$ & $\begin{array}{c}\text { Pump } \\
\text { Tank (L) }\end{array}$ & $\begin{array}{c}\text { Distributio } \\
\text { n Device }\end{array}$ & $\begin{array}{c}\text { Dispersal } \\
\text { Area }\left(\mathbf{m}^{2}\right)\end{array}$ & $\begin{array}{c}\text { Vertical } \\
\text { Separation (m) }\end{array}$ & $\begin{array}{c}\text { USDA Soil } \\
\text { Series }\end{array}$ \\
\hline \multirow{2}{*}{ JWS } & 1987 & 37,800 & 37,800 & 3780 & 18,144 & D-box (2) & 892 & $>4 \mathrm{~m}$ & Autryville \\
WCH & 1997 & 73,827 & 73,827 & 11,340 & 11,340 & LPP (2) & 1115 & $>1 \mathrm{~m}$ & Tarboro \\
\hline
\end{tabular}

\subsection{Groundwater Monitoring Network}

Monitoring wells constructed with 3.2 or $5 \mathrm{~cm}$ diameter, solid PVC pipe coupled to $0.90 \mathrm{~m}$ of well screen were installed near (within $3 \mathrm{~m}$ ) the corners of both drainfields at each site ( 25 m apart) (Figure 2 and Figure 3). Therefore, there were a total of four "front" wells (closest to distribution box/mainfold) and four "end" wells (farthest from the distribution box/manifold). Soil augers and a geoprobe were used to create bore holes to depths below the water table (range: $1 \mathrm{~m}$ to $10.5 \mathrm{~m}$ ) for well placement. Once the wells were placed and driven in the boreholes, the annular space adjacent to the screen was filled with sand, and the annular space above the screen was filled with a mixture of native sand and bentonite. The wells were capped, labeled, and enclosed in valve boxes. The relative elevation of the monitoring wells was determined using a laser level, and the coordinates of the wells 
were determined using a Trimble 6000 series GPS (Trimble Navigation Limited, Westminster, CO, USA). Site maps with the monitoring well locations overlain on aerial photographs were created for both sites. Depth to groundwater was determined using a Solinst TLC meter (Solinst, Ontario, Canada), and the relative elevation of the groundwater was labeled on the maps. Groundwater flow direction was determined using the groundwater data, and the 3-pt contouring method [24]. Monitoring wells were installed up-gradient and down-gradient from the systems at both sites, after the groundwater flow direction was determined. A spring and stream and were also sampled at JWS down-gradient from the OWS.

Figure 2. James Smith Elementary School (JWS) in Craven County, North Carolina. The blue circles show monitoring wells, (DG) is down-gradient wells, the red boxes show the boundaries of drainfields 1 and 2. The fronts of the drainfields are located on the west side of the boxes, while the ends of the drainfields are located on the east side of the boxes. Groundwater flow direction is to the north.

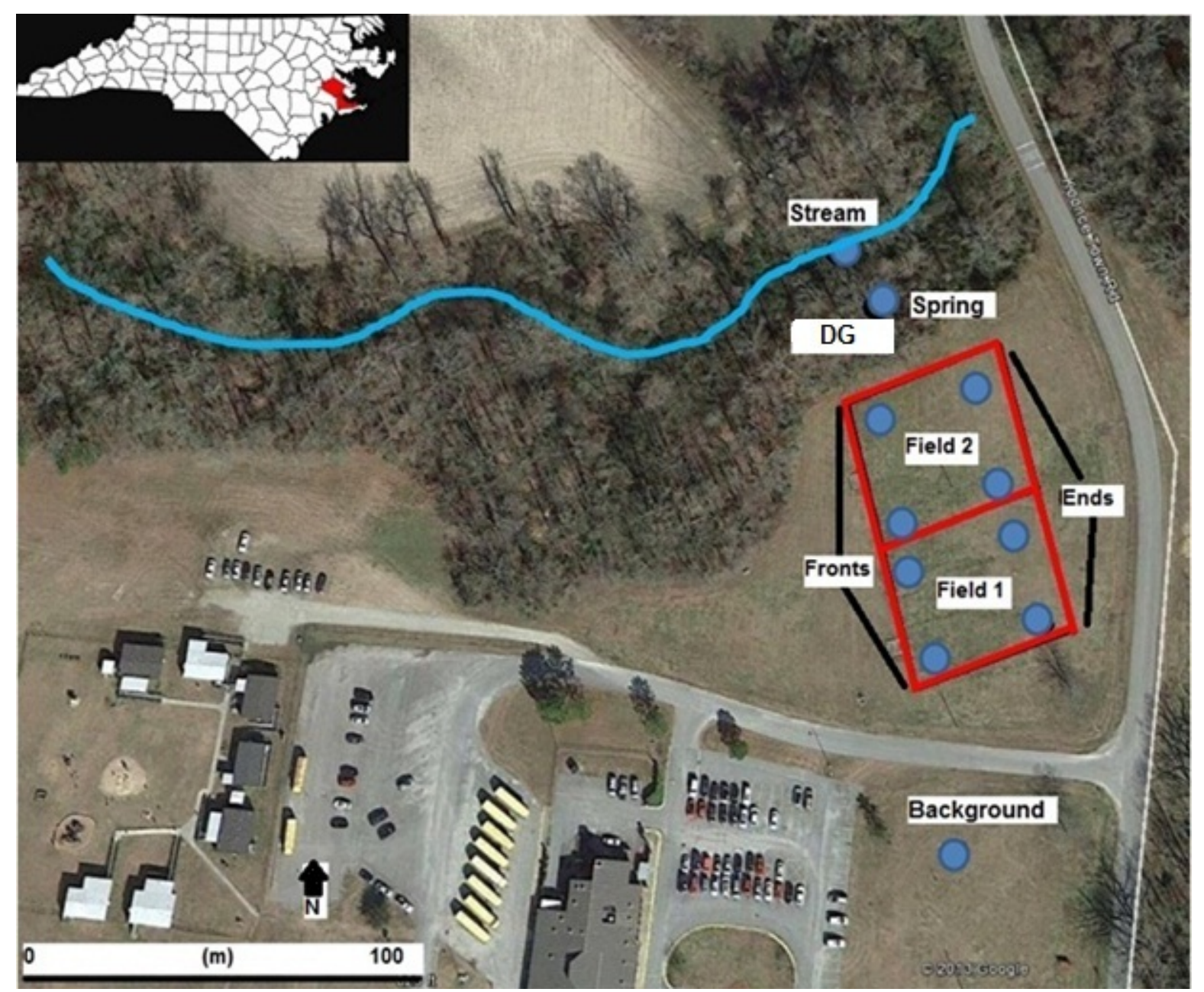


Figure 3. West Craven High School (WCH) in Craven County, North Carolina. The blue circles show the location of monitoring wells, the red boxes show drainfields 1 and 2 . The fronts of the drainfields are located on west side of the boxes, while the ends of the drainfields are located on the east side of the boxes. Groundwater flow direction is to the north.

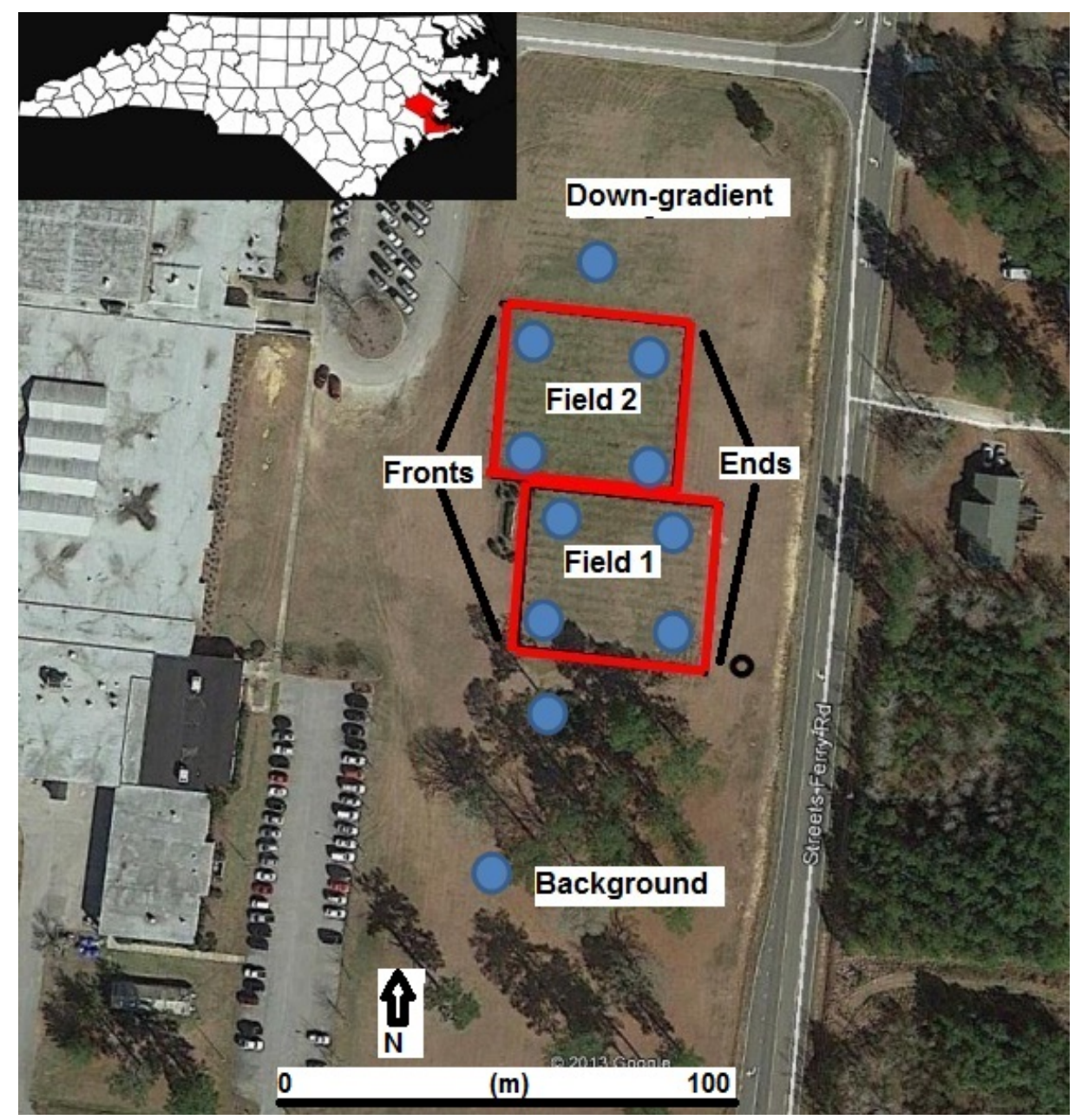

\subsection{Groundwater Characterization and Analysis}

Environmental readings and water samples were collected bi-monthly (4 times) during the study period (November 2012 to May 2013) from each well, septic tank, and adjacent surface water. Samples were collected during periods without rainfall to help reduce the potential for sample contamination. The depth to groundwater at each well was determined using a Solinst TLC meter (Solinst, Ontario, Canada). The well was then purged using a sterile (unwrapped immediately prior to use) bailer, allowed to recharge, and a sample was transferred from the bailer to sterile sample bottle. New, neoprene gloves were used for each sample location. Sample bottles were labeled and placed in ice filled coolers for later transport to the East Carolina University Environmental Health Sciences Water Laboratory for analysis. Samples were prepared and incubated within $6 \mathrm{~h}$ of collection. Samples from the bailers were also transferred to the multi-meter sensor cup. An YSI 556 multi-meter (YSI Inc., Yellow Springs, OH, USA) was used to determine sample $\mathrm{pH}$, specific conductivity (SC), and temperature in the field. The meter was calibrated prior to each field day. Septic effluent samples were 
obtained from the distribution box at JWS and from the septic tank at WCH by removing the manhole covers and lowering bailers into the box and tank for sample collection. Effluent samples were also transferred to the sensor cups for environmental readings. Water samples were analyzed for total coliform and E. coli using the IDEXX Colilert method, and for Enterococci using IDEXX Enterolert method (IDEXX Laboratories, Westbrook, Maine). Total coliform and E. coli samples were incubated at $35{ }^{\circ} \mathrm{C}$ for $24 \mathrm{~h}$ and enterococcus samples were incubated at $41{ }^{\circ} \mathrm{C}$ for $24 \mathrm{~h}$ and then read. Septic effluent samples were diluted (dilution factors of 10-2000×) because of elevated FIB concentrations. For quality control and assurance, field blanks were inserted for approximately $10 \%$ of samples.

\subsection{Spatial Distribution of Fecal Indicators}

Groundwater FIB concentrations near the front of each drainfield were compared to groundwater FIB concentrations near the end of each drainfield to determine if there were significant differences in distribution of wastewater and FIB along the length of the drainfield trenches. The data were pooled for each field (Field 1 fronts in comparison to Field 1 ends) and between fields (Field 1 and Field 2 fronts in comparison to Field 1 and Field 2 ends). Groundwater FIB concentrations beneath Field 1 and Field 2 were compared at each site to determine if significant differences were observed between the fields. Mann Whitney tests were performed with Minitab16 statistical software to determine if differences in concentrations were statistically significant. Groundwater physical and chemical properties including $\mathrm{pH}$, specific conductivity (SC), depth from surface, and temperature were also summarized for Fields 1 and 2, and for proximal and distal ends of the drainfields. FIB data were log transformed and a Pearson Correlation test was used to determine if there were significant correlations between the different FIB concentrations, and between FIB concentrations and SC. Correlations between FIB and SC were performed because SC is often elevated in fresh groundwater influenced by effluent $[7,25,26]$.

\subsection{Treatment Efficiency}

FIB concentrations in septic effluent and groundwater beneath the drainfield with the highest FIB concentrations (Field 1 or Field 2 for each site) were compared to determine the effectiveness of the OWS in reducing FIB concentrations in the vadose zone. Septic effluent concentrations of FIB were also compared to groundwater down-gradient and within the flow path of the OWS to determine the effects on groundwater quality down-gradient from the OWS. Groundwater FIB concentrations beneath the drainfield trenches and within the flow paths of the OWS were compared to up-gradient groundwater FIB concentrations to determine if the OWS were influencing groundwater quality. Surface water was also sampled at JWS from a spring located down-gradient and within the groundwater flow path of the OWS, and from an adjacent stream that received the spring discharge. A piezometer adjacent to the spring at JWS was also sampled. Groundwater and surface water FIB concentrations were compared to surface waters standards for the specific indicators. The OWS treatment efficiencies of JWS and WCH were compared. The geometric mean FIB concentrations we observed were not compared to the geometric mean FIB water quality standards for FIB because the sampling frequency used in this study did not conform to the frequency recommended by the US United States Environmental Protection Agency (EPA). The geometric mean FIB concentrations were 
instead compared to the single sample FIB standard for infrequently used surface waters suggested by the US EPA.

\section{Results}

\subsection{Groundwater Enterococci Distribution}

The geometric mean groundwater enterococci concentrations at JWS (MPN/100 mL) were higher towards the end of the drainfield trenches relative to the front of the trenches for Field 1 (Front: 336, End: 1329) and Field 2 (Front: 36; End:149), and for the pooled data (All Fronts: 110, All Ends: 445) (Figure 4). Statistically significant differences in groundwater enterococci concentrations were observed between the end and front of the trenches for Field $1(p=0.05)$ and for the pooled (end $v s$. front) data $(p=0.004)$. Groundwater enterococci concentrations were significantly $(p=0.0035)$ higher beneath Field 1 (667 MPN/100 mL) relative to Field 2 (73 MPN/100 mL). The groundwater geometric mean enterococci concentrations at WCH were elevated toward the end of the trenches beneath Field 1 (End: $1196 \mathrm{MPN} / 100 \mathrm{~mL}$; Front: $562 \mathrm{MPN} / 100 \mathrm{~mL}$ ) and lower toward the end of the trenches beneath Field 2 (Front: $123 \mathrm{MPN} / 100 \mathrm{~mL}$; End: $92 \mathrm{MPN} / 100 \mathrm{~mL}$ ), but the differences were not statistically significant $(p>0.10)$ (Figure 4$)$. When pooling the data, groundwater towards the end of drainfields (geometric mean enterococci concentrations: $331 \mathrm{MPN} / 100 \mathrm{~mL}$ ) was not significantly different than groundwater towards the front of the trenches (geometric mean: $262 \mathrm{MPN} / 100 \mathrm{~mL}$ ). Groundwater enterococci concentrations were significantly $(p=0.001)$ higher beneath Field $1(820 \mathrm{MPN} / 100 \mathrm{~mL})$ relative to Field $2(106 \mathrm{MPN} / 100 \mathrm{~mL})$. All field blanks $(n=12)$ were negative for FIB.

Figure 4. Enterococci concentrations (Log MPN/100 mL) in groundwater beneath the drainfields at James W. Smith (a) and West Craven High (b). Field 1 is F1, Field 2 is F2, front of the field is F, end of the field is E. Data indicate that groundwater enterococci concentrations were significantly higher near the ends of the trenches relative to fronts of the trenches at James Smith, and beneath Field 1 relative to Field 2 at James Smith and West Craven.

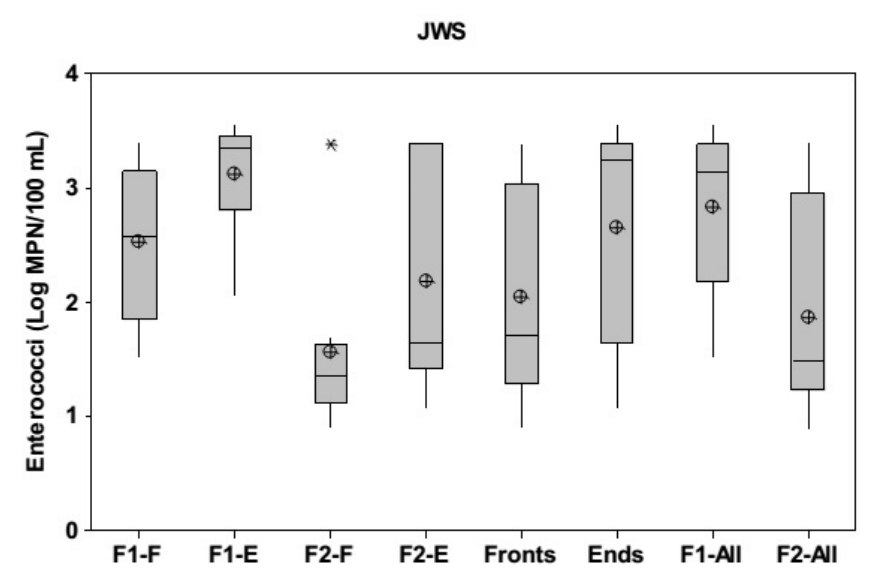

(a)

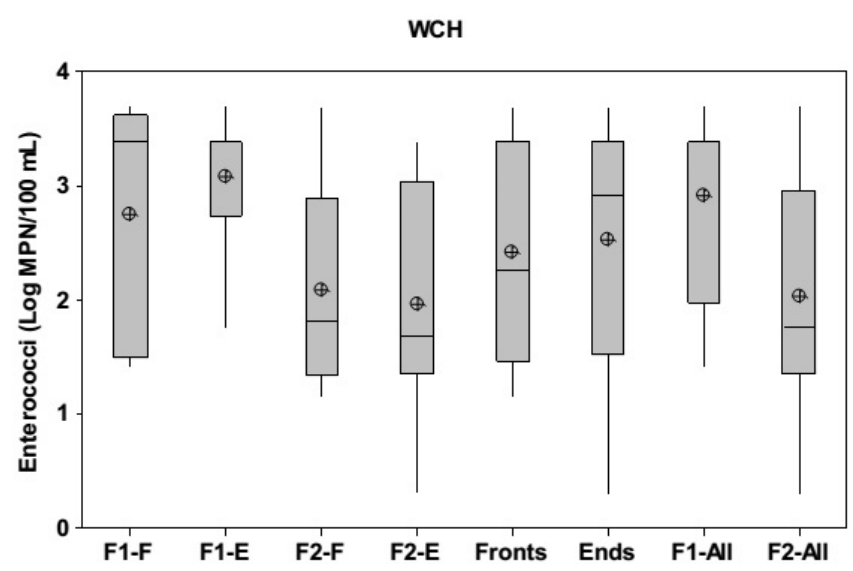

(b) 


\subsection{Groundwater Total Coliform Distribution}

The geometric mean total coliform concentrations in groundwater towards the end of Field 2 (1341 MPN/100 ML) was similar to groundwater coliform concentrations near the front (1034 MPN/100 mL), and for the pooled data (Fronts: 1507, Ends: 1568) (Figure 5). The groundwater total coliform concentrations were elevated beneath Field 1 (2007 MPN/100 mL) in comparison to Field $2(1178 \mathrm{MPN} / 100 \mathrm{~mL}$ ) and the differences were statistically significant (at $p \leq 0.10)$. There was a weak, but significant correlation between enterococci and total coliform concentrations at JWS $(r=0.446, p=0.011)$. Groundwater total coliform concentrations near the end and front of trenches beneath Field 1 (End: $1071 \mathrm{MPN} / 100 \mathrm{~mL}$; Front: $518 \mathrm{MPN} / 100 \mathrm{~mL}$ ) and Field 2 at WCH (Front: $1140 \mathrm{MPN} / 100 \mathrm{~mL}$; End: $300 \mathrm{MPN} / 100 \mathrm{~mL}$ ) were not significantly different (Figure 5). Overall, pooled data revealed that groundwater near the front of the drainfield trenches had similar geometric mean total coliform concentrations (748 MPN/100 mL) in comparison to groundwater near the end of the trenches (592 MPN/100 mL). Groundwater beneath Field 1 had similar geometric mean coliform concentrations $(744 \mathrm{MPN} / 100 \mathrm{~mL})$ in relation to groundwater beneath Field 2 (585 MPN/100 mL). There was a weak correlation between enterococci and total coliform concentrations at $\mathrm{WC}(r=0.328$, and $p=0.07)$.

Figure 5. Coliform concentrations (Log MPN/100 mL) in groundwater beneath the drainfields at James W. Smith (a) and West Craven High (b). Field 1 is F1, Field 2 is F2, front of the field is F, end of the field is E. Data indicate that groundwater coliform concentrations were evenly distributed beneath the systems at both sites.

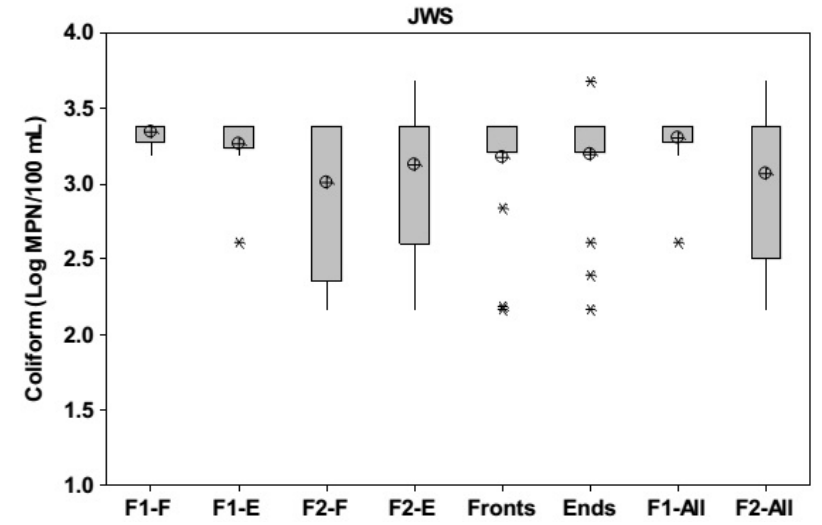

(a)

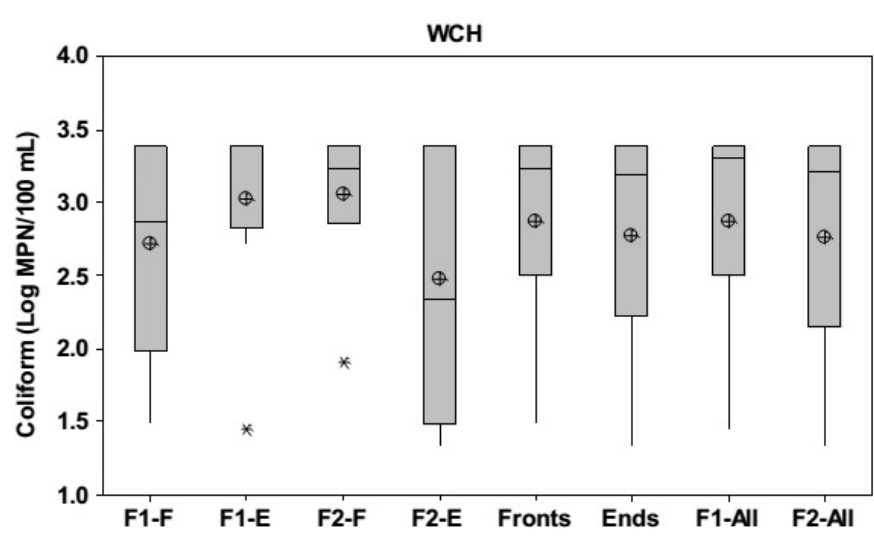

(b)

\subsection{Groundwater E. coli Distribution}

The mean groundwater E. coli concentrations were higher at JWS near the end of the trenches beneath Field $1(7 \mathrm{MPN} / 100 \mathrm{~mL})$ and Field $2(2 \mathrm{MPN} / 100 \mathrm{~mL})$ relative to the end of trenches (Field 1 Front: $1 \mathrm{MPN} / 100 \mathrm{~mL}$, Field 2 Front: $1 \mathrm{MPN} / 100 \mathrm{~mL}$ ) (Figure 6). Differences were significant at $p=0.097$. Groundwater beneath Field 1 had similar average $E$. coli concentrations ( $4 \mathrm{MPN} / 100 \mathrm{~mL})$ to groundwater beneath Field $2(2 \mathrm{MPN} / 100 \mathrm{~mL})$. The mean groundwater E. coli concentrations at WCH towards the front of the trenches for Field $1(8 \mathrm{MPN} / 100 \mathrm{~mL})$ and Field $2(4 \mathrm{MPN} / 100 \mathrm{~mL})$ were similar to concentrations near the end of the trenches (Field 1 End: $4 \mathrm{MPN} / 100 \mathrm{~mL}$; Field 2 
End: $1 \mathrm{MPN} / 100 \mathrm{~mL}$ ) (Figure 6). The pooled data also showed similar mean concentrations of E. coli in groundwater towards to the front of the trenches $(6 \mathrm{MPN} / 100 \mathrm{~mL})$ in comparison to the end (3 MPN/100 mL), and beneath Field $1(6 \mathrm{MPN} / 100 \mathrm{~mL})$ than Field 2 (3 MPN/100 mL).

Figure 6. $E$. coli concentrations (Log MPN/100 mL) in groundwater beneath the drainfield trenches at James W. Smith (a) and West Craven High (b). Field 1 is F1, Field 2 is F2, front of the field is F, end of the field is E. Data indicate that the E. coli concentrations were more variable at James W. Smith relative to West Craven.

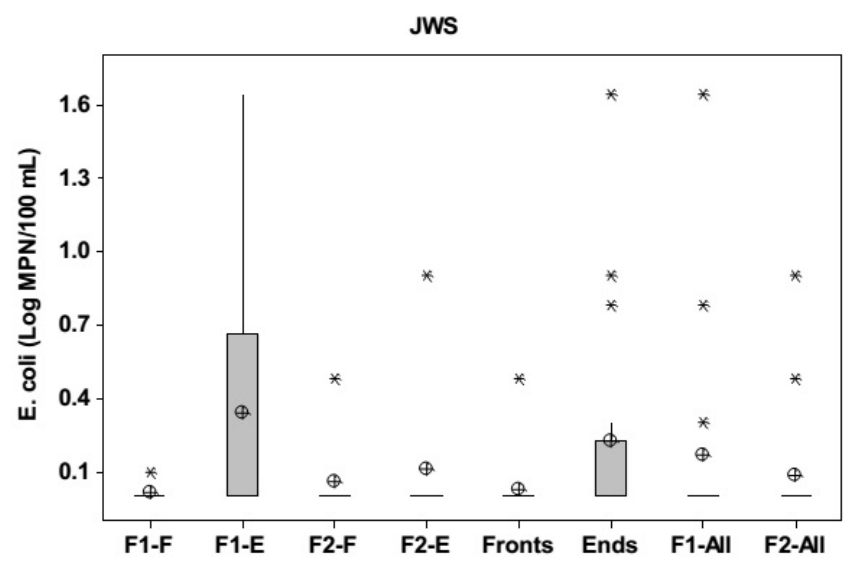

(a)

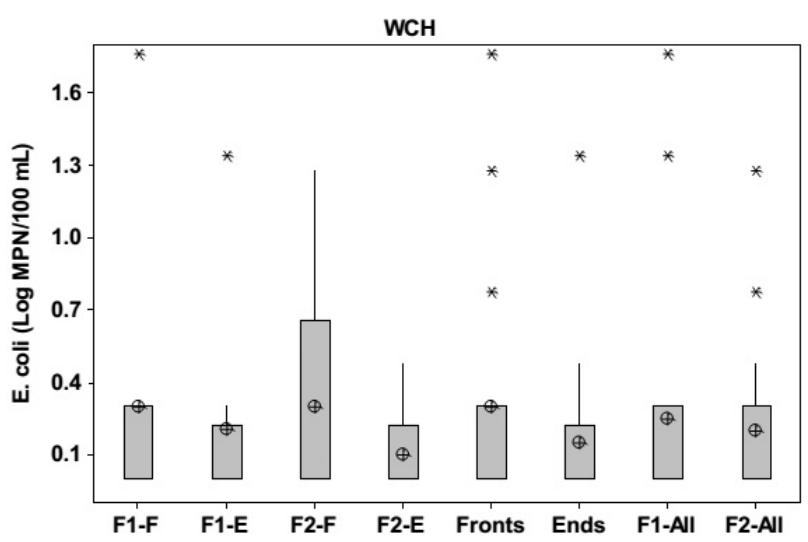

(b)

\subsection{Microbial Treatment}

The OWS at JWS was efficient $(>99 \%)$ at reducing all FIB concentrations before discharge to groundwater and adjacent surface water. Wastewater geometric mean FIB concentrations from the septic tank (enterococci: 296,669 MPN/100 mL; total coliform: 1,104,391 MPN/100 mL; and E. coli: 457,809 MPN/100 mL) were significantly higher (all $p<0.05$ ) than all other sampling locations. Between the JWS septic tank and groundwater beneath the field with the highest FIB concentrations (Field 1), there were significant reductions in the concentrations of enterococci ( $\log 2.65$ reduction or $99.78 \%$ ), total coliform $(\log 2.74$ reduction or $99.82 \%)$ and E. coli $(\log 5.06$ reduction or $>99.99 \%$ ) (Figure 7). Groundwater enterococci and total coliform (but not E. coli) concentrations beneath portions of Field 1 were significantly elevated relative to background groundwater (enterococci: $105 \mathrm{MPN} / 100 \mathrm{~mL}$; total coliform: $267 \mathrm{MPN} / 100 \mathrm{~mL}$; E. coli: $0 \mathrm{MPN} / 100 \mathrm{~mL}$ ). Microbe concentrations at JWS were further reduced as groundwater moved $24 \mathrm{~m}$ down-gradient from the OWS (enterococci: $57 \mathrm{MPN} / 100 \mathrm{~mL}$; total coliform: $1418 \mathrm{MPN} / 100 \mathrm{~mL}$; E. coli: < 1 MPN/100 mL). Surface water microbe concentrations at the spring down-gradient from the OWS (enterococci: $4 \mathrm{MPN} / 100 \mathrm{~mL}$; total coliform: $149 \mathrm{MPN} / 100 \mathrm{~mL}$; E. coli: $3 \mathrm{MPN} / 100 \mathrm{~mL}$ ) were less than or similar to background groundwater concentrations, and surface water standards. The overall FIB concentration reductions at JWS from septic tank to the spring were significant (enterococci: $\log 4.86$ or $99.98 \%$ reduction; total coliform: $\log 3.87$ or $99.87 \%$ reduction; and E. coli: $\log 5.18$ or $>99.99 \%$ reduction). Creek water upstream from where the spring discharges into the stream contained elevated concentrations of all microbial indicators (enterococci: $71 \mathrm{MPN} / 100 \mathrm{~mL}$; total coliform: $1221 \mathrm{MPN} / 100 \mathrm{~mL}$; and E. coli: $291 \mathrm{MPN} / 100 \mathrm{~mL}$ ). 
The OWS at WCH was also efficient at reducing all measured wastewater FIB concentrations before discharge to groundwater beneath the drainfields (Figure 7). There was a $\log 2.16$ reduction (99.30\%) in enterococci concentrations from the septic tank (117,532 MPN/100 mL) to groundwater beneath Field 1 ( $820 \mathrm{MPN} / 100 \mathrm{~mL})$. Groundwater enterococci concentrations beneath Field 1 were still significantly $(p=0.03)$ higher than background groundwater $(52 \mathrm{MPN} / 100 \mathrm{~mL})$. Similar to JWS, the OWS at WCH also had elevated geometric mean enterococci $(820 \mathrm{MPN} / 100 \mathrm{~mL})$ relative to the single sample standard for infrequently used recreational waters (151 MPN/100 mL) [27]. However, there was a $\log 3.75$ reduction (99.98\%) between the septic tank and groundwater $10 \mathrm{~m}$ down-gradient (21 MPN/100 mL) from the drainfield, and at that distance, enterococci concentrations were not significantly different than background groundwater.

Figure 7. Fecal indicator bacteria concentrations (Log MPN/100 mL) data at James W. Smith (a) and West Craven High (b) for background groundwater (BG), septic tank effluent (Tank), groundwater beneath the drainfield with the highest microbial concentrations (F1-All), down-gradient groundwater (DG), spring water (Spring) and stream (Up-stream). Data indicate excellent treatment (>99\% reduction) for all indicator bacteria from the septic tanks to groundwater, and further treatment as indicator bacteria concentrations decrease in groundwater down-gradient from the systems. Enterococci reductions are the lowest.

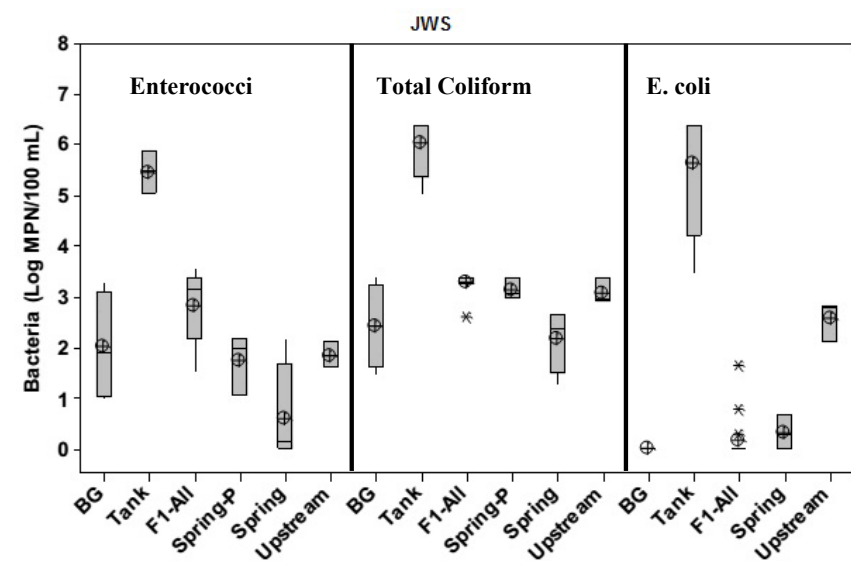

(a)

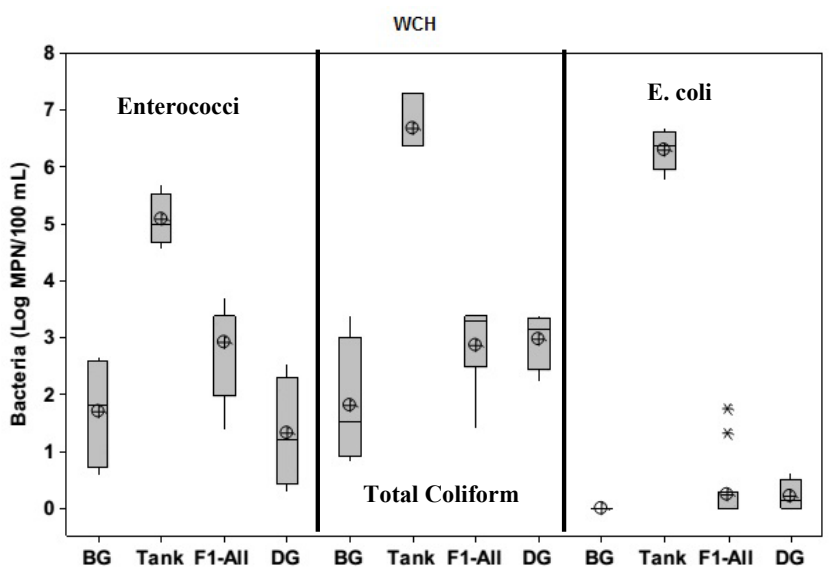

(b)

There was a $\log 3.87$ reduction (99.98\%) in total coliform at $\mathrm{WCH}$ between the septic tank (4,859,918 MPN/100 mL) and groundwater beneath Field 1 (744 MPN/100 mL). Total coliform concentrations did not change much $10 \mathrm{~m}$ down-gradient from the OWS (949 MPN/100 mL). Background groundwater total coliform concentrations (65 MPN/100 mL) were lower than all other sampling locations, but statistically significant differences were only observed when comparing septic wastewater to background groundwater. Septic wastewater coliform concentrations were significantly $(p<0.05)$ higher than all other sampling locations. The geometric mean total coliform concentrations beneath Field 1 and down-gradient from the OWS were lower than total coliform surface water standards (1000 MPN/100 mL) used by some countries [28].

There was a $\log 5.63$ reduction $(>99.99 \%)$ in E. coli concentrations between the septic tank $(2,573,800 \mathrm{MPN} / 100 \mathrm{~mL})$ and groundwater beneath Field $1(6 \mathrm{MPN} / 100 \mathrm{~mL})$, and a $\log 6.11$ reduction $(>99.99 \%)$ between the tank and groundwater $10 \mathrm{~m}$ down-gradient $(2 \mathrm{MPN} / 100 \mathrm{~mL})$ from 
the OWS at WCH. Septic tank E. coli concentrations were significantly higher than all other sampling locations. Groundwater E. coli concentrations beneath the OWS were lower than surface water standards for E. coli (geometric mean: $126 \mathrm{MPN} / 100 \mathrm{~mL}$; single sample: $576 \mathrm{MPN} / 100 \mathrm{~mL}$ ) [27].

\subsection{Physical and Chemical Parameters}

The mean SC at each site was highest for wastewater samples from the septic tanks (JWS: $1057 \pm 387 \mu \mathrm{S} / \mathrm{cm}$; WCH: $1196 \pm 432 \mu \mathrm{S} / \mathrm{cm}$ ) (Table 2). Groundwater beneath the drainfields and down-gradient from the OWS had SC significantly $(p<0.05)$ higher than background groundwater for both sites (Table 2). The spring at JWS also had elevated SC $(620 \pm 69 \mu \mathrm{S} / \mathrm{cm})$ relative to background groundwater $(98 \pm 51 \mu \mathrm{S} / \mathrm{cm})$ and stream water $(144 \pm 12 \mu \mathrm{S} / \mathrm{cm})$. Groundwater SC trends were similar to microbial concentration trends at JWS. More specifically, the average groundwater SC was higher beneath Field $1(755 \mu \mathrm{S} / \mathrm{cm})$ relative to Field $2(547 \mu \mathrm{S} / \mathrm{cm})$, and higher towards the end of the trenches $(754 \mu \mathrm{S} / \mathrm{cm})$ relative to the front $(547 \mu \mathrm{S} / \mathrm{cm})$. At $\mathrm{WCH}$, groundwater SC trends were similar to microbe trends because the average SC was elevated near the front of the trenches $(521 \mu \mathrm{S} / \mathrm{cm})$ relative to the ends of the trenches $(340 \mu \mathrm{S} / \mathrm{cm})$. However, there were some dissimilarities as mean groundwater SC was elevated beneath Field $2(550 \mu \mathrm{S} / \mathrm{cm})$ relative to Field $1(312 \mu \mathrm{S} / \mathrm{cm})$, while microbe concentrations were typically higher beneath Field 1 at WCH. There were weak but significant correlations between SC and enterococci concentrations at JWS $(r=0.428, p=0.007)$ and WCH $(r=0.387, p=0.014)$ and between SC and total coliform concentrations at WC $(r=0.534, p=0.001)$.

Sample $\mathrm{pH}$ values were highest for wastewater at each site (JWS: $7.31 \pm 0.26$; WCH: $6.91 \pm 0.28$ ), and were generally similar to or elevated in groundwater beneath the drainfields (JWS: 6.37 to 6.89; WCH: 5.97 to 6.53 ) relative to background groundwater (JWS: $5.12 \pm 0.65$; WCH: $6.56 \pm 0.99$ ).

Table 2. Mean and standard deviation (in brackets) physical and chemical properties of water at various sampling locations at James W. Smith and West Craven High. Data indicate higher mean specific conductivity values for groundwater influenced by wastewater.

\begin{tabular}{cccccc}
\hline \multirow{2}{*}{ Site } & $\begin{array}{c}\text { Sampling } \\
\text { Location }\end{array}$ & $\begin{array}{c}\text { Specific Conductivity } \\
(\boldsymbol{\mu S} / \mathbf{c m})\end{array}$ & $\mathbf{p H}$ & Temp $\left({ }^{\circ} \mathbf{C}\right)$ & $\begin{array}{c}\text { Depth to Water } \\
(\mathbf{m})\end{array}$ \\
\hline \multirow{6}{*}{ JWS } & Field 1 & $753(246)$ & $6.37(0.57)$ & $18.3(1.1)$ & $4.56(0.91)$ \\
& Field 2 & $547(237)$ & $6.89(0.75)$ & $18.9(1.1)$ & $6.21(1.02)$ \\
& Front & $547(204)$ & $6.45(0.80)$ & $18.4(0.9)$ & $4.92(1.25)$ \\
& Ends & $754(268)$ & $6.78(0.58)$ & $18.8(1.2)$ & $5.85(1.15)$ \\
& Background & $98(51)$ & $5.12(0.65)$ & $18.1(0.5)$ & $4.32(0.31)$ \\
& Tank & $1057(387)$ & $7.31(0.26)$ & $17.8(2.9)$ & - \\
& Down-gradient & $620(69)$ & $7.23(0.27)$ & $17.5(0.8)$ & $0.34(0.02)$ \\
& Spring & $445(29)$ & $6.91(0.37)$ & $18.2(0.6)$ & - \\
& Upstream & $144(12)$ & $7.22(0.25)$ & $13.7(1.1)$ & - \\
\hline \multirow{6}{*}{ WCH } & Field 1 & $312(401)$ & $5.97(0.65)$ & $16.4(2.1)$ & $1.76(0.16)$ \\
& Field 2 & $550(302)$ & $6.53(0.34)$ & $16.7(1.8)$ & $1.62(0.11)$ \\
& Front & $521(327)$ & $6.32(0.55)$ & $16.6(2.0)$ & $1.69(0.16)$ \\
& Ends & $340(397)$ & $6.17(0.63)$ & $16.4(1.9)$ & $1.69(0.16)$ \\
& Background & $49(12)$ & $6.56(0.99)$ & $15.5(2.2)$ & $1.53(0.31)$ \\
& Tank & $1196(432)$ & $6.91(0.28)$ & $17.9(3.5)$ & - \\
& Down-gradient & $710(212)$ & $6.53(0.22)$ & $17.2(1.5)$ & $1.44(0.13)$ \\
\hline
\end{tabular}


Water temperature at JWS was similar for the septic tank wastewater $\left(17.8 \pm 2.9{ }^{\circ} \mathrm{C}\right)$, groundwater beneath the drainfields $\left(18.3\right.$ to $\left.18.9^{\circ} \mathrm{C}\right)$, and spring $\left(18.2 \pm 0.6{ }^{\circ} \mathrm{C}\right)$. The average stream water temperature at JWS was lower $\left(13.7 \pm 1.1^{\circ} \mathrm{C}\right)$ than the groundwater and wastewater temperatures.

The average depth to groundwater near the drainfield area at JWS (4.56 to $6.21 \mathrm{~m}$ ) was greater than at $\mathrm{WCH}(1.62$ to $1.76 \mathrm{~m})$. There was also more variability in groundwater depths between Fields 1 and 2 at JWS (mean difference of $1.55 \mathrm{~m}$ ) in comparison to $\mathrm{WCH}$ (mean difference of $0.14 \mathrm{~m}$ ).

\section{Discussion}

\subsection{Microbial Distribution}

Overall, the OWS at WCH had a more uniform distribution of FIB in groundwater beneath the system than the OWS at JWS. More specifically, statistically significant differences $(p<0.05)$ were observed when comparing the groundwater enterococci concentrations near the end of the trenches relative to the front of the trenches at JWS, but not at WCH. Higher concentrations of enterococci concentrations in groundwater towards the ends of the trenches at JWS may have been because of the formation of a biomat near the front of the trenches that reduced the infiltration rate of effluent and bacteria at JWS near the front [17,29-31]. Biomats form along the trench bottom and trench sidewalls as solids, microorganisms, and secretions from microorganisms accumulate and begin to clog soil pores and reduce the infiltration rate of wastewater into the soil. Biomat formation is influenced by, dosing characteristics, hydraulic and organic loading rate, age of the system, and aeration status of the infiltrative surface [30,32,33]. While both OWS used pump stations, and thus had effluent dosing and resting times, the OWS at WCH used low-pressure pipe (LPP) distribution. The LPP system may have provided more even distribution of wastewater across the drainfield area, and limited the development of a biomat relative to JWS, or allowed a more even development of a biomat along the trenches. Prior studies have shown that OWS that use LPP can be effective at reducing microbial concentrations, in theory, because of the uniform distribution of effluent and the resting and dosing cycles which promote unsaturated flow $[19,20]$. Research has also shown that effluent distribution via distribution box, like at JWS, can often be unequal [5,9]. When effluent leaves the distribution boxes and enters the drainfield trenches at JWS, effluent initially leaks out of the closely spaced, relatively large holes in the pipes at the front of the trenches, thus dosing the front the of the trenches first, and resulting in a relatively high hydraulic and organic loading rate near the front of the trenches [30]. Overtime, a biomat forms at the front of the trenches and gradually extends towards the end, as effluent infiltration is reduced via the biomat and effluent is "pushed" along the length of the trench [30]. The OWS at JWS had been in use for 25 years prior to the start of this study. This may explain why groundwater enterococci, total coliform, E. coli concentrations and SC were higher towards the end of the trenches at JWS, because of the biomat formation at the front of the trenches that limited infiltration of wastewater near the front. Biomat formation can enhance the treatment of effluent by reducing the infiltration rate of wastewater into soil, creating unsaturated flow conditions beneath the OWS trenches, and increasing the residence time of wastewater in the vadose zone [30-32]. However, if the biomat does not extended to the distal end of the trenches, then uneven distribution and treatment of effluent along the trench may occur, potentially influencing groundwater quality dynamics beneath OWS. Biomat formation 
takes time. The OWS at WCH and JWS had been is use for 15 years and 25 years respectively, prior to the start of this project, so there was more time for biomat formation at JWS. However, the maximum design wastewater loading rate to drainfield trenches at WCH $\left(66.2 \mathrm{~L} / \mathrm{m}^{2} / \mathrm{d}\right)$ was greater than at JWS $\left(42.4 \mathrm{~L} / \mathrm{m}^{2} / \mathrm{d}\right)$, thus increasing the potential for biomat development at $\mathrm{WCH}$. The higher loading rates at $\mathrm{WCH}$ were a reflection of the NC regulations for the design and installation of OWS [21].

There were consistent patterns of elevated enterococci, total coliform and E. coli concentrations beneath Field 1 relative to Field 2 at both sites. For the JWS site, this is somewhat expected because there was a significant difference in the depth to groundwater beneath Field $1(4.56 \pm 0.91 \mathrm{~m})$ relative to Field $2(6.21 \pm 1.02 \mathrm{~m})$. Therefore, the vadose zone was on average over $1.6 \mathrm{~m}$ thicker beneath Field 2 relative to Field 1 at JWS. Prior studies have shown that bacteria treatment typically improves as the unsaturated zone thickness increases $[7,8,12,14,15,26]$. Therefore, there was likely more bacterial filtration beneath Field 2, relative to Field 1. At WCH, the depth to groundwater was very similar beneath Field $1(1.76 \pm 0.16 \mathrm{~m})$ and Field $2(1.62 \pm 0.11 \mathrm{~m})$. The groundwater samples were collected during a period (November-May) when the water table is typically highest in eastern NC [22]. Therefore, it is possible the treatment efficiencies of the OWS may improve during the summer, when the water table is lower, and vadose zone is thicker.

There were significant differences in groundwater SC near the end of the drainfield trenches at JWS $(754 \pm 268 \mu \mathrm{S} / \mathrm{cm})$ relative to the front of the trenches $(547 \pm 204 \mu \mathrm{S} / \mathrm{cm})$, and beneath Field 1 $(753 \pm 246 \mu \mathrm{S} / \mathrm{cm})$ in comparison to Field $2(547 \pm 237 \mu \mathrm{S} / \mathrm{cm})$. Because wastewater contains elevated concentration of dissolved salts and solids, the SC of wastewater is elevated relative to most fresh groundwater, and SC has been used as a tracer for wastewater impacted groundwater [34,35]. The SC patterns were very similar to the microbial indicator patterns at JWS (both higher for Field 1 relative to Field 2, and higher towards the end of the trenches relative to front). At $\mathrm{WCH}$, there were also statistically significant differences $(p<0.05)$ in groundwater SC beneath the front $(521 \pm 327 \mu \mathrm{S} / \mathrm{cm})$ and ends of the trenches $(340 \pm 397 \mu \mathrm{S} / \mathrm{cm})$, and beneath Field $1(312 \pm 401 \mu \mathrm{S} / \mathrm{cm})$, relative to Field 2 $(550 \pm 302 \mu \mathrm{S} / \mathrm{cm})$. However the differences at WCH (Fronts $>$ Ends: $p=0.050$; and Field $2>$ Field 1: $p=0.011$ ) were not as significant as at JWS (Ends > Fronts: $p=0.0167$; Field $1>$ Field 2: $p=0.0070$ ). Therefore, the groundwater SC also showed a more even distribution at WCH with the LPP system in comparison to JWS with the pump to distribution box system.

While some of the differences in microbial concentrations between Fields 1 and 2 at JWS may have been influenced by the differences in vadose zone thickness, there was still more variation in groundwater microbe concentrations between the front and end of the trenches for each individual field (less variability in vadose zone thickness) at JWS in relation to $\mathrm{WCH}$, indicating that effluent distribution was a key factor in groundwater microbial concentrations.

\subsection{Treatment}

There was significant attenuation ( $>99 \%$ ) of all microbial indicators between the septic tank and groundwater for both systems. Total coliform were most abundant in all sampling locations at both sites. The OWS at WCH was on average, more efficient (Log 3.87 or 99.98\%) at reducing total coliform concentrations prior to discharge to groundwater than the OWS at JWS (Log 2.74 or 99.82\%). However, the OWS at JWS was more efficient at reducing enterococci (Log 2.65 or 99.78\%) in 
comparison to $\mathrm{WCH}(\log 2.16$ or $99.30 \%)$. The average $E$. coli treatment at the two sites were similar (JWS: 5.06 or $>99.99 \%$; WCH: 5.63 or $>99.99 \%$ ). Overall, the OWS at both sites were less efficient at reducing enterococci, relative to the other bacteria, and thus enterococci was the most resilient of the microbial indicators.

While FIB concentration reduction was efficient, groundwater with elevated concentrations of enterococci and total coliform were still observed beneath the OWS trenches at JWS. For example the geometric mean enterococci concentration beneath F1 (667 MPN/100 mL) was elevated relative to the single sample recreational surface water standard for infrequently used waters (151 MPN/100 mL) [27]. The United States Environmental Protection Agency has not set a surface water standard for total coliform, because coliform bacteria grow in soil and are not specific to fecal material, however, other countries such as Columbia, Cuba, and Japan have total coliform standards for recreational waters of $1000 \mathrm{MPN} / 100 \mathrm{~mL}$ [28]. The geometric mean total coliform concentration beneath JWS (Field 1) was 2007 MPN/100 mL, and thus would have exceeded standards established by other countries. However, FIB concentrations at JWS were further reduced as groundwater moved $24 \mathrm{~m}$ down-gradient from the OWS (enterococci: $57 \mathrm{MPN} / 100 \mathrm{~mL}$; total coliform: $1418 \mathrm{MPN} / 100 \mathrm{~mL}$; E. coli: < 1 MPN/100 mL). Surface water microbe concentrations at the spring down-gradient from the OWS (enterococci: $4 \mathrm{MPN} / 100 \mathrm{~mL}$; total coliform: $149 \mathrm{MPN} / 100 \mathrm{~mL}$; E. coli: $3 \mathrm{MPN} / 100 \mathrm{~mL}$ ) were less than or similar to background groundwater concentrations, and surface water standards. Therefore, FIB transport to surface water was limited at JWS because of the combined effects of the vertical separation from OWS trenches to groundwater and the horizontal setback distances from surface water, resulting in efficient overall treatment (enterococci: Log 4.86 or $99.98 \%$ reduction; total coliform: Log 3.87 or $99.87 \%$ reduction; and E. coli: $\log 5.18$ or $>99.99 \%$ reduction). Creek water upstream from where the spring discharges into the stream contained elevated concentrations of all FIB (enterococci: $71 \mathrm{MPN} / 100 \mathrm{~mL}$; total coliform: $1221 \mathrm{MPN} / 100 \mathrm{~mL}$; and E. coli: $291 \mathrm{MPN} / 100 \mathrm{~mL}$ ) indicating another source of surface water FIB contamination in the watershed.

Groundwater typically had higher enterococci concentrations than E. coli, but surface waters typically had higher E. coli relative to enterococci. Prior studies have also reported that OWS typically are not as effective at reducing enterococci relative to E. coli [8-10]. Transport of FIB beyond $10 \mathrm{~m}$ from the OWS was very limited, and groundwater FIB concentrations were typically at or below background concentrations 10 to $24 \mathrm{~m}$ down-gradient from the OWS. While the spring at JWS did contain detectable levels of all FIB (Enterococci: 4 MPN/100 mL; Total Coliform: 222 MPN/100 mL; E. coli: $2 \mathrm{MPN} / 100 \mathrm{~mL}$ ), the mean spring FIB concentrations were lower than surface water sampled $5 \mathrm{~m}$ upstream from where the spring discharged into the creek (Enterococci: $71 \mathrm{MPN} / 100 \mathrm{~mL}$; Total Coliform: $1221 \mathrm{MPN} / 100 \mathrm{~mL}$; E. coli: $291 \mathrm{MPN} / 100 \mathrm{~mL}$ ). Therefore, other sources of FIB pollution may have been influencing stream water quality. Research has shown that pets [36], livestock [37], wildlife [38], and various other non-point sources of pollution [39] can contribute significant concentrations of FIB to surface waters. There are some livestock farms upstream from JWS, sparse residential development with OWS, and wildlife such as raccoons, birds, and deer have been seen in riparian areas adjacent to the stream. Studies have also shown that surface waters near OWS may have FIB concentrations that are elevated relative to groundwater near properly functioning and malfunctioning systems [8-10]. 


\section{Conclusions}

Overall, there was a more even distribution of FIB in groundwater beneath the LPP system at WCH in comparison to the pump to distribution box system at JWS. The groundwater SC was also more similar beneath the drainfield at WCH in relation to JWS. Both systems were very effective ( $>99 \%)$ at reducing FIB concentrations before discharge to groundwater, and FIB concentrations were typically at background groundwater concentrations 10 to $24 \mathrm{~m}$ down-gradient from the OWS. The OWS at both sites were less efficient at reducing enterococci concentrations in relation to E. coli and total coliform treatment.

\section{Acknowledgments}

The authors would like to thank the North Carolina Water Resources Research Institute and the East Carolina University Coastal Water Resources Center for partial funding of this research. The authors would also like to acknowledge the assistance that John Woods, Jim Watson, Sarah Hardison, Matt Smith, Eliot Anderson-Evans, Caitlin van Dodewaard, and Amberlynne VanDusen provided with field and/or lab work and data compilation.

\section{Author Contributions}

All authors contributed to the conception, field and/or lab work, and development of this manuscript.

\section{Conflicts of Interest}

The authors declare no conflict of interest.

\section{References}

1. United States Environmental Protection Agency (USEPA). On-site Wastewater Treatment Systems Manual; EPA/625/R-00/008; USEPA: Washington, DC, USA, 2002; pp. 1-11.

2. Carroll, S.; Hargreaves, M.; Goonetilleke, A. Sourcing faecal pollution from onsite wastewater treatment systems in surface waters using antibiotic resistance analysis. J. Appl. Microbiol. 2005, 99, 471-482.

3. Harman, J.; Robertson, W.D.; Cherry, J.A.; Zanini, L. Impacts on a sand aquifer from an old septic system: Nitrate and phosphate. Groundwater 1996, 34, 1105-1114.

4. Pang, L.; Close, M.; Goltz, M.; Sinton, L.; Davies, H.; Hall, C.; Stanton, G. Estimation of septic tank setback distances based on transport of E. coli and F-RNA phages. Environ. Int. 2003, 29, 907-921.

5. Patel, T.; O’Luanaigh, N.O.; Gill, L.W. A Comparison of gravity distribution devices used in On-site domestic wastewater treatment systems. Water Air Soil Pollut. 2008, 191, 55-69.

6. Lowe, K.S.; Rothe, N.K.; Tomaras, J.M.B.; DeJong, K.; Tucholke, M.B.; Drewes, J.; McCray, J.E.; Munakata-Marr, J. Influent constituent characteristics of the modern waste stream rom single sources. In Literature Review; Water Environment Research Foundation: Alexandria, VA, USA, 2007; pp. 3-19. 
7. Humphrey, C.P.; O’Driscoll, M.A.; Zarate, M.A. Evaluation of on-site wastewater system Escherichia coli contributions to shallow groundwater in coastal North Carolina. Water Sci. Technol. 2011, 63, 789-795.

8. Conn, K.E.; Habteselassie, M.Y.; Blackwood, A.D.; Noble, R.T. Microbial water quality before and after the repair of a failing onsite wastewater treatment system adjacent to coastal waters. J. Appl. Microbiol. 2011, 112, 214-224.

9. Habteselassie, M.Y.; Kirs, M.; Conn, K.E.; Blackwood, A.D.; Kelly, G.; Noble, R.T. Tracking microbial transport through four onsite wastewater treatment systems to receiving waters in eastern North Carolina. J. Appl. Microbiol. 2011, 111, 835-847.

10. Harris, J.; Humphrey, C.; O'Driscoll, M. Transport of indicator microorganisms from an onsite wastewater system to adjacent stream. Univers. J. Environ. Res. Technol. 2013, 3, 423-426.

11. Cahoon, L.B.; Hales, J.C.; Carey, E.S.; Loucaides, S.; Rowland, K.R.; Nearhoof, J.E. Shellfishing closures in southwest Brunswick County, North Carolina: Septic tanks vs. stormwater runoff as fecal coliform sources. J. Coast. Res. 2006, 22, 319-327.

12. Meeroff, D.; Bloetscher, F.; Bocca, T.; Morin, F. Evaluation of water quality impacts of on-site wastewater treatment and disposal systems on urban coastal waters. Water Air Soil Pollut. 2008, 192, 11-24.

13. Borchardt, M.A.; Po-Huang, C.; DeVries, E.O.; Belongia, E.A. Septic system density and infectious diarrhea in a defined population of children. Environ. Health Perspect. 2003, 111, 742-748.

14. Scandura, J.E.; Sobsey, M.D. Viral and bacterial contamination of groundwater from on-site sewage treatment systems. Water Sci. Technol. 1997, 35, 141-146.

15. Karathanasis, A.D.; Mueller T.G.; Boone, B.; Thompson, Y.L. Effect of soil depth and texture on fecal bacteria removal from septic effluents. J. Water Health 2006, 4, 395-404.

16. Ijzerman, M.M.; Hagedorn, C.; Reneau, R.B. Microbial tracers to evaluate an on-site shallow-placed low pressure distribution system. Water Res. 1993, 27, 343-347.

17. O'Luanaigh, N.D.; Gill, L.W.; Misstear, B.D.R.; Johnston, P.M. The attenuation of microorganisms in on-site wastewater effluent discharged into highly permeable subsoils. J. Contam. Hydrol. 2012, 142-143, 126-139.

18. Motz, E.C.; Cey, E.; Ryan, M.C.; Chu, A. Vadose zone microbial transport below at-grade distribution of wastewater effluent. Water Air Soil Pollut. 2012, 223, 771-785.

19. Carlile, B.L.; Cogger, C.G.; Sobsey, M.D.; Scandura, J.; Steinbeck, S.J. Movement and Fate of Septic Tank Effluent in Soils of the North Carolina Coastal Plain; Report to the Coastal Plains Regional Commission: Raleigh, NC, USA, October 1981; p. 37.

20. Ijzerman, M.M.; Hagedorn, C.; Reneau, R.B. Fecal indicator organisms below an on-site wastewater system with low pressure pipe distribution. Water Air Soil Pollut. 1992, 63, 201-210.

21. North Carolina Division of Environmental Health: On-site Wastewater Section. Laws and Rules for Sewage Treatment and Disposals Systems, Raleigh, NC, USA 1999; Available online: http://ehs.ncpublichealth.com/oswp/resources.htm (accessed on 11 March 2014).

22. U.S. Department of Agriculture, Natural Resources Conservation Service. Soil Survey of Craven County, North Carolina, USA 1989. Available online: http://soils.usda.gov/survey/printed_surveys/ (accessed on 11 March 2014). 
23. Blott, S.; Pye, K. Gradistat: A grain size distribution and statistics package for the analysis of uncosolidated sediments. Earth Surf. Process. Landf. 2001, 26, 1237-1248.

24. Domenico, P.A.; Schwartz, W. Physical and Chemical Hydrogeology, 2nd ed.; John Wiley \& Sons, Inc.: New York, NY, USA, 1998; p. 36.

25. Del Rosario, K.L.; Humphrey, C.P.; Mitra, S.; O’Driscoll, M.A. Nitrogen and carbon dynamics beneath on-site wastewater treatment systems in pitt county, North Carolina. Water Sci. Technol. 2014, 69, 663-671.

26. Humphrey, C.P.; O'Driscoll, M.A. Biogeochemistry of groundwater beneath on-site wastewater systems in a coastal watershed. Univers. J. Environ. Res. Technol. 2011, 1, 320-328.

27. United States Environmental Protection Agency (USEPA). Managing Urban Watershed Pathogen Contamination; EPA/600/R-03/111; USEPA: Cincinnati, OH, USA, 2003.

28. United States Environmental Protection Agency. Ambient Water Quality Criteria for Bacteria; EPA440/5-84-002; USEPA: Washington, DC, USA, 1986.

29. Stevik, T.K.; Aa, K.; Ausland, G.; Hanssen, J.F. Retention and removal of pathogenic bacteria in wastewater percolating through porous media: A review. Water Res. 2004, 38, 1355-1367.

30. Hoover, M.T.; Disy, T.A.; Pfieffer, M.A.; Dudley, N.; Mayer, R.B.; Buffington, B. North Carolina Subsurface Wastewater Operators Training School Manual; Soil Science Department, College of Agriculture and Life Sciences, North Carolina State University, Raleigh, NC, USA; North Carolina Department of Environment, Health and Natural Resources: Raleigh, NC, USA, 1996.

31. Beal, C.D.; Gardner, E.A.; Kirchhof, G.; Menzies, N.W. Long-term flow rates and biomat zone hydrology in soil columns receiving septic tank effluent. Water Res. 2006, 40, 2327-2338.

32. Siegrist, R.; Boyle, W.C. Wastewater-induced soil clogging development. J. Environ. Eng. 1987, $113,550-566$.

33. Stevik, T.K.; Ausland, G.; Jenssen, P.D.; Siegrist, R. Removal of E. coli during intermittent filtration of wastewater effluent as affected by dosing rate and media type. Water Res. 1999, 33, 2088-2098.

34. Alhajjar, B.J.; Chesters, G.; Harkin, J.M. Indicators of Chemical Pollution from Septic Systems. Groundwater 1990, 28, 559-568.

35. Humphrey, C.P.; Deal, N.E.; O’Driscoll, M.A.; Lindbo, D.L. Characterization of on-site wastewater nitrogen plumes in shallow coastal aquifers, North Carolina. In Proceedings of the 2010 World Environmental \& Water Resources Congress, Providence, RI, USA, 16-20 May 2010; pp. 949-958.

36. Wright, M.E.; Solo-Gabriele, H.M.; Elmir, S.; Fleming, L.E. Microbial load from animal feces at a recreational beach. Mar. Pollut. Bull. 2009, 58, 1649-1656.

37. Liwimbi, L.; Graves, A.K.; Israel, D.W.; van Heugten, E.; Robinson, B.; Cahoon, C.W.; Lubbers, J.F. Microbial source tracking in a watershed dominated by swine. Water 2010, 2, 587-604.

38. Whitlock, J.E.; Jones, D.T.; Harwood, V.J. Identification of the sources of fecal coliforms in an urban watershed using antibiotic resistance analysis. Water Res. 2002, 36, 4237-4282.

39. Sanders, E.C.; Yuan, Y.; Pitchford, A. Fecal coliform and E. coli concentrations in effluent-dominated streams of the Upper Santa Cruz Watershed. Water 2013, 5, 243-261.

(C) 2014 by the authors; licensee MDPI, Basel, Switzerland. This article is an open access article distributed under the terms and conditions of the Creative Commons Attribution license (http://creativecommons.org/licenses/by/3.0/). 